\title{
THE INVOLVEMENT OF THE BANKING SECTOR IN CO-FINANCING EUROPEAN FUNDED PROJECTS PROPOSED BY ROMANIAN PRIVATE COMPANIES
}

\author{
Laurențiu Droj $^{1}$
}

ABSTRACT: The European Integration came with new challenges for the Romanian enterprises especially for the SMEs, the opportunities arising from operating on the European Single Market and the possibility for accession of European Structural Funds. This article will tackle with the issue of access of the Romanian SME's to European funding. The New Definition of SME's will be presented as an important tool for implementing efficient measures in order to raise the accessibility of European financing programmes. Will be analyzed and presented the main European Financing programmes. A higher emphasis will be made towards programmes which are intending to directly support strengthening and upgrading of the productive sector The third part of this paper will analyze and present the role of the banking sector, within this field of activity, both in the preparation and implementation stages of the private European funded investment projects.

Key words: SME, European financing, European Union, European Funded Programs, Banking, National Guarantee Fund for SMEs

JEL codes: G38, G21, G32, F36, F35

\section{Introduction}

The European Integration came with new challenges for the Romanian enterprises especially for SMEs, the opportunities arising from operating on the European Single Market and the possibility for accession of European Structural Funds. Together with SMEs from other accession candidates Romanian SMEs reformed themselves in order to comply with the European Regulations, to accommodate to their new positions given by "The New SME Definition" and to access succesfully the European Funds specially tailored for them.

In the same time the banking system created new services which were dedicated to SMEs in need of support for development, implementation or cofinancing of European funded investment projects. In this context, also, the role of the National Guarantee Fund for SMEs (Fondul Naţional de Garantare pentru Întreprinderile Mici şi Mijlocii - FNGCIMM) changed and the fund becamed an important actor which can offer guarantees for the investment loans offered by the financial system.

\section{The new SME definition - Literature review}

In a single market with no internal frontiers, it is essential that measures in favor of SMEs are based on a common definition to improve their consistency and effectiveness, and to limit distortions of competition. This is all the more necessary given the extensive interaction between national and EU measures to help SMEs in areas such as regional development and research funding. In 1996, a recommendation establishing a first common SME definition was adopted by the Commission. This definition has been widely applied throughout the European Union. On 6 May 2003, the Commission adopted a new recommendation in order to take account of economic developments since 1996. It entered into force on 1 January 2005 and will apply to all the policies, programmes and measures that the Commission operates for SMEs. As mentioned in the "The New

\footnotetext{
${ }^{1}$ University of Oradea, str. Universității nr. 1 Oradea, laurentiu.droj@gmail.com
} 
SME Definition - User Guide and Model Declaration”, for Member States use of the definition is voluntary, but the Commission is inviting them, together with the European Investment Bank and the European Investment Fund to apply it as widely as possible.

According to the European Office of Statistics the average European enterprise employs no more than six people, so most of the enterprises can be considered as SMEs. However, the new definition takes into account possible relationships with other enterprises. In certain cases, those relationships, particularly if they create significant financial links with other enterprises, may imply that an enterprise is not an SME. This is the only way to ensure that only enterprises which genuinely require support are targeted by public schemes. For this reason, it introduces methods to calculate the staff and financial thresholds to gain a more realistic picture of the economic situation of an enterprise. A distinction has been introduced between different types of enterprises: autonomous, partner and linked.

As mentioned above the Article 2 of the Annex of Recommendation 2003/361/EC considers that "The category of micro, small and medium-sized enterprises (SMEs) is made up of enterprises which employ fewer than 250 persons and which have an annual turnover not exceeding 50 million euro, and/or an annual balance sheet total not exceeding 43 million euro." The first step to qualify as an SME is to be considered as an enterprise. According to the new definition, an enterprise is "any entity engaged in an economic activity, irrespective of its legal form". By being formally included in the recommendation, the scope of the new SME definition is now clearly marked out. Thus, the self-employed, family firms, partnerships and associations regularly engaged in an economic activity may be considered as enterprises.

\section{SMEs categories based on their headcount and annual financial data - Research methodology}

In order to check if an entity is an SME the first step is to verify if it is an enterprise. Further it must be established the data of the analyzed enterprise according to the following three criteria: staff headcount, annual turnover and annual balance sheet.

Comparing the data of the analyzed company with the thresholds for the three criteria will allow determining whether the company is a micro, small or medium-sized enterprise. It is necessary to note that while it is compulsory to respect the staff headcount thresholds, an SME may choose to meet either the turnover or balance sheet ceiling. The new definition offers this choice since, by their nature, enterprises in the trade and distribution sectors, have higher turnover figures than those in manufacturing. Providing an option between this criterion and the balance sheet total, which reflects the overall wealth of an enterprise, ensures that SMEs engaged in different types of economic activity are treated fairly. The distribution of the companies in the micro, small or medium-sized enterprises categories is presented in the figure no. 1.

The staff headcount is a crucial initial criterion for determining in which category an SME falls. It covers full-time, part-time and seasonal staff and includes the following:

- Employees, persons working for the enterprise being subordinated to it and considered to be employees under national law,

- Owner-managers, partners engaged in a regular activity in the enterprise and benefiting from financial advantages from the enterprise.

The staff headcount is expressed in annual work units (AWU). Anyone who worked full-time within an enterprise, or on its behalf, during the entire reference year counts as one unit. The parttime staff, seasonal workers and those who did not work the full year are treated as fractions of one unit. As mentioned in the User Guide the annual turnover is determined by calculating the income that the enterprise received during the year in question from its sales and services after any rebates have been paid out. Turnover should not include value added tax (VAT) or other indirect taxes (Article 28 of Council Directive 78/660/EEC). The annual balance sheet total refers to the value of the company's main assets (Article 12.3 of Council Directive 78/660/EEC ). 


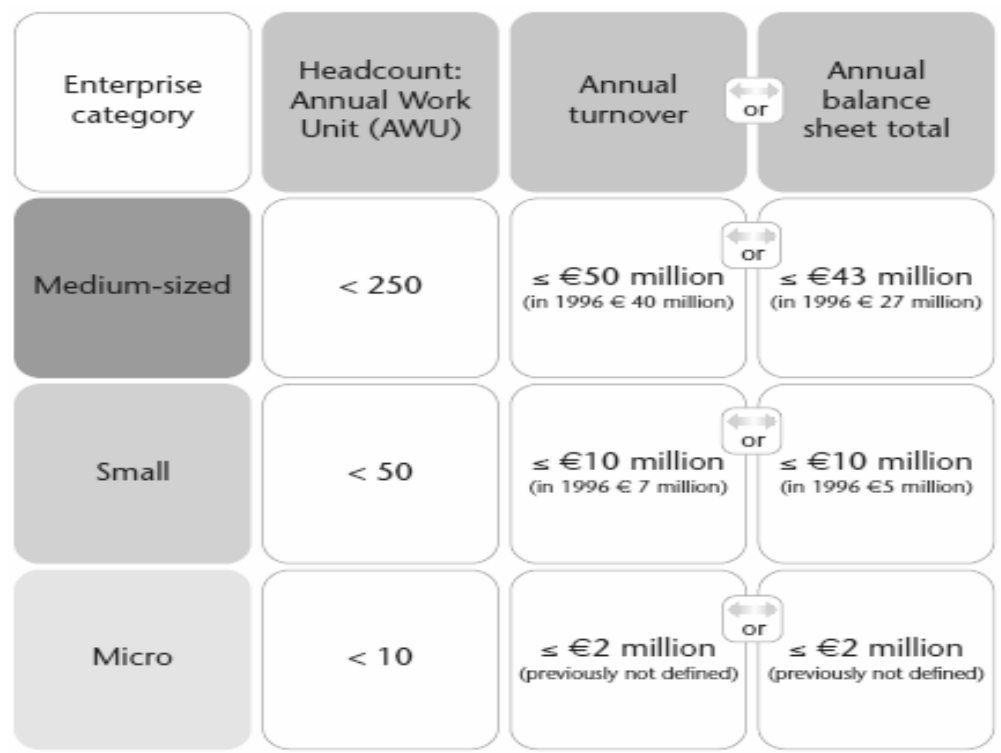

Figure no.1. Categories of SMEs according to the new thresholds (Extract from "The New SME Definition - User Guide and Model Declaration", p. 14)

\section{Research - The main financing programs which are directly supporting strengthening and upgrading of the private productive sector}

Once the company is considered an SME and is classified as being one of the main type of SMEs: micro-enterprise, small enterprise or medium-sized enterprise, can be evaluated which are the main financing opportunities available for each of those types and which is the maximum level of European funding eligible. Different financing programs have been created for different types of SMEs based on their size, based on their location (in a rural or urban area), and based on their specific area of activity. This paper proposes to analyze only the European Funding Programs available only for private enterprises which are directly supporting strengthening and upgrading of the productive sector by tangible and intangible private investments. Further in this chapter will be presented only two of the financing programs which offer support to the SME's and large enterprises in order to increase their competitiveness and to increase their productive capacity: The Regional Operational Programme - Major Field of Intervention 4.3 "Support the development of micro-enterprises" and Sectorial Operational Programme "Increase of Economic Competitiveness".

\section{Regional Operational Programme - The main choice for financing infrastructure development of urban micro-enterprises}

For micro-enterprises, located in the urban areas, which consider to upgrade their the main financing program which is addressed to them is The Regional Operational Program(ROP), major Field of Intervention 4.3. "Support the development of micro-enterprises".

ROP, the biggest operational programme which operates in Romania, has as its strategic objective supporting the economic, social, territorially balanced and sustainable development of the Romanian Regions, according to their specific needs and resources, focusing on urban growth poles, improving the business environment and basic infrastructure, in order to make the Romanian Regions, especially the ones lagging behind, more attractive places to live, visit, invest in and work. This objective will be achieved through a differentiated financial allocation by Regions, according to their level of development and in close coordination with the actions implemented by other Operational Programmes. The coordination will be achieved at programme level through a clear definition of intervention areas under different programmes and projects, using comparable selection criteria and coordinated decision-making process. 


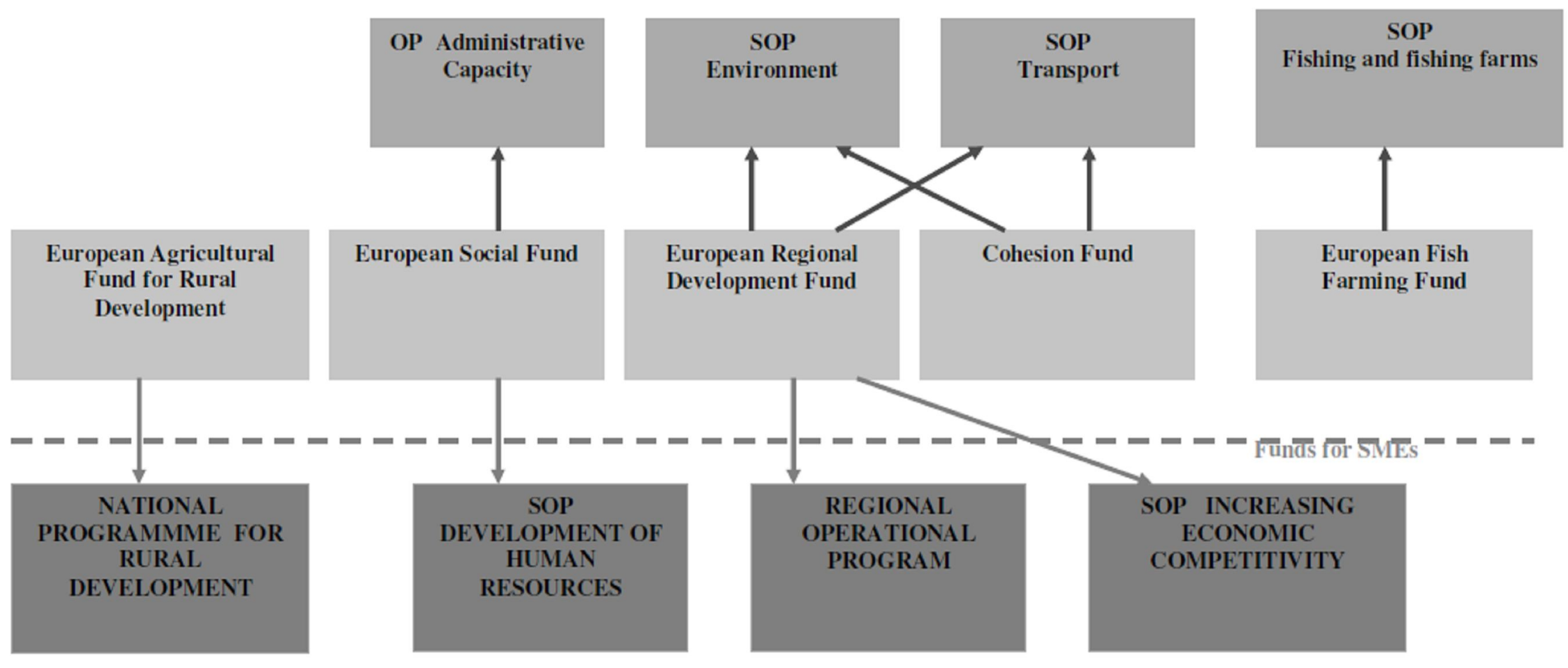

Figure no. 2. Major financing sources for SMEs

(Adapted from "Ghid de Informare Privind Fondurile Structurale", edited by Fondul Național de Garantare a Creditelor pentru IMM-uri, 2008) 
Taking into consideration the revised Lisbon strategy, it is also necessary to invest in the modernization of local and regional productive sectors, by supporting entrepreneurship and facilitating the development of micro enterprises.

ROP considers that micro-enterprises will play an important role in regional/local economic development and job creation. Due to this fact, it is extremely important for the ROP to support a friendly entrepreneurship climate in the local communities, by facilitating the creation of new businesses and the development of existing ones. Furthermore, key activities for ensuring regional and local prosperity consist in supporting technological transfers to micro enterprises, in line with the Regional Innovation Strategies (RIS).

The support for local/regional micro-enterprises aims at restructuring lagging behind areas, with economic growth potential especially the small and medium towns and as a result new jobs will be created due to the fact that they have the necessary flexibility to adapt to the demands of a dynamic market economy. The Regional Operational Programme supports the establishment and development of productive and service micro-enterprises and use of the endogenous potential of the Regions (natural resources, raw materials, human resources, etc). Furthermore, micro-enterprises will be encouraged to use new technologies and innovations, IT equipments and services with an essential role in increasing competitiveness, productivity and quality of services. The financing of micro-enterprises may also involve different types of financial engineering instruments (JEREMIE).

Indicative operations financed by ROP are:

- Support to micro-enterprises' development

- Procurement of equipments and modern productive technologies, services, constructions;

- Procurement of IT systems (software and equipments);

- Use of new technologies in the current activities of micro-enterprises;

- Relocation of the micro-enterprises in business structure;

- Extension/ construction/ rehabilitation/ modernization of the micro-enterprises production spaces;

- Specific development activities.

The regional competitive advantages and the regional disparities will be taken into consideration at the level of the gross investment. Priority will be given to those economic activities with potential competitive advantages, identified in Regional Development Strategies.

The financial allocation for the period 2007-2013, for the major domain of intervention 4.3 "Support the development of micro-enterprises" is approximately of 200.09 millions of euro (European Regional Development Fund). The distribution of this financial allocation between the development regions is presented in the below table (millions EUR):

Table no. 1

Distribution of the financial allocation between the development regions ROP, 4.3

\begin{tabular}{|l|l|l|l|l|l|l|l|l|}
\hline Region & $\begin{array}{l}\text { North } \\
\text { East }\end{array}$ & $\begin{array}{l}\text { South } \\
\text { East }\end{array}$ & South & $\begin{array}{l}\text { South } \\
\text { West }\end{array}$ & West & $\begin{array}{l}\text { North } \\
\text { West }\end{array}$ & Center & $\begin{array}{l}\text { Bucharest } \\
\text { Ilfov }\end{array}$ \\
\hline $\begin{array}{l}\text { Financial } \\
\text { Allocation }\end{array}$ & 32,66 & 26,51 & 28,47 & 28,03 & 20,69 & 24,19 & 21,81 & 17,73 \\
\hline
\end{tabular}

Source: "Ghidul Solicitantului - Axa prioritară 4 „,Sprijinirea dezvoltării mediului de afaceri regional şi local” Domeniul de intervenție 4.3. ,, Sprijinirea dezvoltării microîntreprinderilor,”,

- version 30.10.2009

Increasing the management and productive capacity of Romanian small, medium and large enterprises by accession of structural funds - SOP IEC

The Sectorial Operational Programme "Increase of Economic Competitiveness" (further referred to as SOP IEC) is one of the seven instruments (Operational Programs), which offer the financial support for the consolidation and modernization of productive sector through investments. 
The SOP IEC aims to strengthen the strategic focus of the Economic and Social Cohesion policies across Romania, and to make the correct and appropriate linkages to the European policies and the Lisbon Strategy for growth and job creation.

The general objective of SOP is the increase of Romanian companies' productivity, in compliance with the principle of sustainable development, and to reduce the disparities compared to the average productivity of the European Union. The target is an average annual growth of GDP per employed person by about $5.5 \%$. This will allow Romania to reach an approximate of $55 \%$ of the EU average productivity by 2015 .

The Priority Axis 1: An innovative and eco-efficient productive system of the Sectorial Operational Programme "Increase of Economic Competitiveness" refers to the efforts of supporting enterprises, especially SMEs, and will concentrate both on improving the market conditions linked to the development of the industrial base, in order to revive the business environment and generate new innovative enterprises, as well as on developing of the business sector, improving the access to capital and fostering technological development. The objectives which are set to be fulfilled by this priority axis are:

- Consolidation and sustainable growth of the Romanian productive sector

- Establishment of a favorable environment for enterprises' development.

The main key areas of intervention, divided in subprograms, are:

- D1.1.Productive and environment friendly investments and preparation for market competition, especially of SMEs

- D 1.2. Access to finance for SMEs

- D 1.3. Sustainable entrepreneurship development

From the above mentioned areas of intervention the main instrument of the SOP IEC in order to support and finance quality improvement of the production processes of the Romanian companies is the area of intervention "D1.1. Productive and environment friendly investments and preparation for market competition, especially of SMEs."

The specific objective of this key area is represented by the consolidation and sustainable growth of the Romanian productive sector can be accomplished through:

- The revival of the productive sector based on extension and modernization, by investments in new technology, equipment, machineries and by acquisition of patents, trademarks, licenses and know-how,

- Innovation of production both concerning the production processes and the products,

- Adaptation to European and International Standards and certification of management systems,

- Access of the Romanian companies to new markets

- Promotion of sustainable development, decreasing of the negative impact on the environment and growing the international competitiveness.

The following indicative operations are established:

1. Support for strengthening and upgrading the productive sector by tangible and intangible investments

2. Support for the implementation of international standards

3. Support to access to new markets and internationalization

For the first indicative operation mentioned above: "D1.1. Productive and environment friendly investments and preparation for market competition, especially of SMEs." a), two state aid schemes are designed, for large enterprises (over 250 employees) and for SMEs with more than 9 employees.

For this operation, the financial support will be paid, through economic and financial appraisal of the applications for funding and in accordance with the provision of art. 57 of Council Regulation No. 1083/2006, in order to avoid any financial support for:

Public funding which would lead to deadweight; 
- Investment deriving from delocalization from other member States in order not to involve the Structural funds in such public funding;

- Enterprises in financial difficulties.

The operation D1.1.a), presented above, supports strengthening and upgrading of the productive sector by tangible and intangible investments for small and medium enterprises (excluding micro enterprises) and also for large enterprises. The operation has a financial allocation of 430 billions lei, in the period 2007-2013, divided between regions as following:

Table no. 2

Financial allocation within the SOP IEC D1.1 a) operation

\begin{tabular}{|l|l|l|}
\hline Nr. & Regions & Financial allocation \\
\hline 1 & Bucharest- Ilfov & 43 billions lei \\
\hline 2 & Regions: Center, North-West, West, South East & 172 billions lei \\
\hline 3 & $\begin{array}{l}\text { Regions: North - East, South Muntenia, South West } \\
\text { Oltenia }\end{array}$ & 215 billions lei \\
\hline
\end{tabular}

(Extract from "Ghidul Solicitantului POS CCE Axa 1 Domeniul 1.1 - Sprijin Financiar în valoare de până la 1.075.000 lei acordat pentru investiții în IMM”, 2009)

The financial support for this operation is $60 \%$ grant for small enterprises in the Region of Bucharest Ilfov, 70\% grant for the small enterprises in other regions of Romania. In case of the middle enterprises they benefit of 50\% grant for those located in the region Bucharest-Ilfov and $60 \%$ grant for the middle enterprises located in other regions of Romania.

Considering the specificity of the SOP IEC programme and especially of the area of intervention "D1.1. Productive and environment friendly investments and preparation for market competition, especially of SMEs" the projects proposed for financing within this operation, are aiming to increase the economic development of the enterprises and the competitiveness of Romanian companies on the European Single Market. In order to fulfill this aims, the following activities are supported within the programme and are considered eligible:

- Creation of new production units,

- Extension of an existent production unit in order to increase capacity of production,

- Diversification of production on an existent site, as a result of initiation new products and services,

- Modernization of the company, including changes of the production technology,

- Acquisition of intangible goods like patents, trademarks, licenses and know-how,

- Consultancies and training services linked with the activities above.

As seen above these activities are mostly encouraging new investments especially in the field of high-tech industry and highly productive industry support services.

The main criteria of selection for financing a project under this field of activity are:

- Relevance of the project for the realization of the objectives of the SOP IEC and especially the contribution brought by the project to the fulfillment of the SOP IEC objectives and especially of the D1.1a) field of intervention.

- Quality and coherence of the project and especially by justification for the need of public financing, by the quality of the technical-financial proposal and by presenting of the correlation between the objectives of the project and the obtained results.

- Maturity of the project and especially the level of preparation of the activities within the project, availability of the land, existence of the technical studies and permits, etc. 
- Sustainability of the project which is concerning mainly the capacity of the applicant to ensure the financial and technical maintenance and operation of the investment for at least three years after the end of the project.

- Capacity of the beneficiary for implementing the project: management capacity, ISO certification, qualification of the management and of the personnel of the applicant.

If these criteria will be met the project will be selected for financing under the framework of SOP IEC programme and especially of the area of intervention "D1.1. Productive and environment friendly investments and preparation for market competition, especially of SMEs". The implementation period for a project developed within this area of intervention is at most 24 months.

Involvement of the Banking Sector in the preparation and implementation stages of the private European funded investment projects

A study which was published in 2006, within a comprehensive analysis of the private sector called "White Charter of Romanian SMEs" revealed that most of the SMEs were using for development mostly their own resources and afterwards bank loans and leasing facilities. This study also underlined the necessity that a switch should be made and a large share of the amounts invested by SME's in their development should be coming from European Financing. As can be observed the role of the Romanian SME Guarantee Fund seems to be insignificant.

SMEs financing sources by size classes

Table no. 3

\begin{tabular}{|l|c|c|c|}
\hline \multicolumn{1}{|c|}{ Financing sources } & \multicolumn{3}{c|}{ Percentage in total SMEs } \\
\cline { 2 - 4 } & Micro & Small & Medium \\
\hline Own resources & 79.53 & 74.30 & 77.95 \\
\hline Bank loans & 37.84 & 59.78 & 72.44 \\
\hline Leasing & 20.10 & 41.62 & 58.27 \\
\hline Loans from financial institution & 1.74 & 3.35 & 7.87 \\
\hline Factoring & 1.12 & 5.59 & 11.02 \\
\hline $\begin{array}{l}\text { Guarantees from the Romanian } \\
\text { SME Guarantee Fund }\end{array}$ & 0.12 & 0.00 & 0.00 \\
\hline Other financing sources & 0.37 & 0.56 & 0.79 \\
\hline
\end{tabular}

Source: White Charter of Romanian SMEs, 2006

After the launch in 2008 of the main European financing programs, focused on the competitive development of the SME's, a switch seems to be in place. Record number of SMEs applied for financial support under different programmes, but mainly under ROP and SOP IEC, which were briefly presented above. Instead of this initial success the SMEs which successfully applied and gain access to European funding witnessed a new and more acute problem: lack of financial resources for co-financing the investments or for supporting the costs concerning the initial stages of the project. In these stages of the project the beneficiary of European fund must invest its own financial resources which will be later refunded, by the Management Authority of the Programme, if they are considered eligible.

In this context the beneficiaries of European financing programs turned once again to the banking system for support. And since the European Funding field of activity is considered to be a fruitful one, especially in the period of crisis, the Romanian banks tailor made several package of products and services dedicated to co-finance or/and pre-finance different type of EU funded projects: 
- Loans for pre-financing the EU grants: especially for activities which are realized before the approval of the project until the first approved payment by the Management Authority. These type of loans are rare and are awarded only to companies with high "credentials".

- Loans for co-financing the eligible and non-eligible costs of the investment projects: especially for activities which are realized after the approval of the project until the first approved payment by the Management Authority. Sometimes the loans can be long term investment loans which can be guaranteed with the investment itself, if this is allowed by the Management Authority. The bank may also finance expenses which are not eligible as well as current operating expenses, by granting short or medium term loans, according to financial statements presented by the applicants

- Letter of Guarantee from the Bank - This instrument is mainly used by the beneficiaries of European Funding Programs in order to request a payment in advance: a pre-financing, before the project actually starts. In this case the Management Authority requests the beneficiary to present a Letter of Guarantee from a commercial bank.

- Some banks are offering also assistance in project management during the preparation stages of the project and/or in the implementation period of the project. Even if most of the Romanian commercial banks have this type of services they are not considered important players in the project management consulting market.

In most of the cases the SMEs which apply and gain access to European funding, dedicated for investment in their production capacity, need bank loans for co-financing and cannot guarantee with their own properties or assets. In this case these SMEs and the banks request the intervention of the National Guarantee Fund for SMEs (Fondul Naţional de Garantare pentru Întreprinderile Mici şi Mijlocii - FNGCIMM). FNGCIMM was founded in december 2001, on the basis of the Law $133 / 1999$ regarding the stimulation of the private entrepreneurs in orde to develop small and medium enterprises.

The strategic objectives of the FNGCIMM are:

- Increasing the access to financing of the small and medium enterprises, which have viable investment proposals, but do not detain adequate material guaranties or financial resources.

- Increasing the volume of investments realized by SMEs;

- Sustaining the economic and social policy of the Government, especially in the field of SMEs

The Fund cooperates with the financial institutions based on working agreements, in which are the underlined the main obligations of the two sides, the value and type of guarantee, the payment protocol for the guarantee involved.

Many Banks present in Romanian have concluded agreements with the FNGCIMM in order to help SMEs by allowing them access to funds allocated by the European Union for the development of the productive sector sector. The banks, as co-financing partner of the projects, will help SMEs access European funds quicker and easier, based on the guarantees of the FNGCIMM.

The FNGCIMM will guarantee at most $80 \%$ of investment loans and up to 800.000 EUR (FNGCIMM, 2008), awarded for co-financing the beneficiaries of European Funds, dedicated to the SMEs such as: ROP, SOP IEC, etc..

The financing mechanism is presented briefly bellow: 


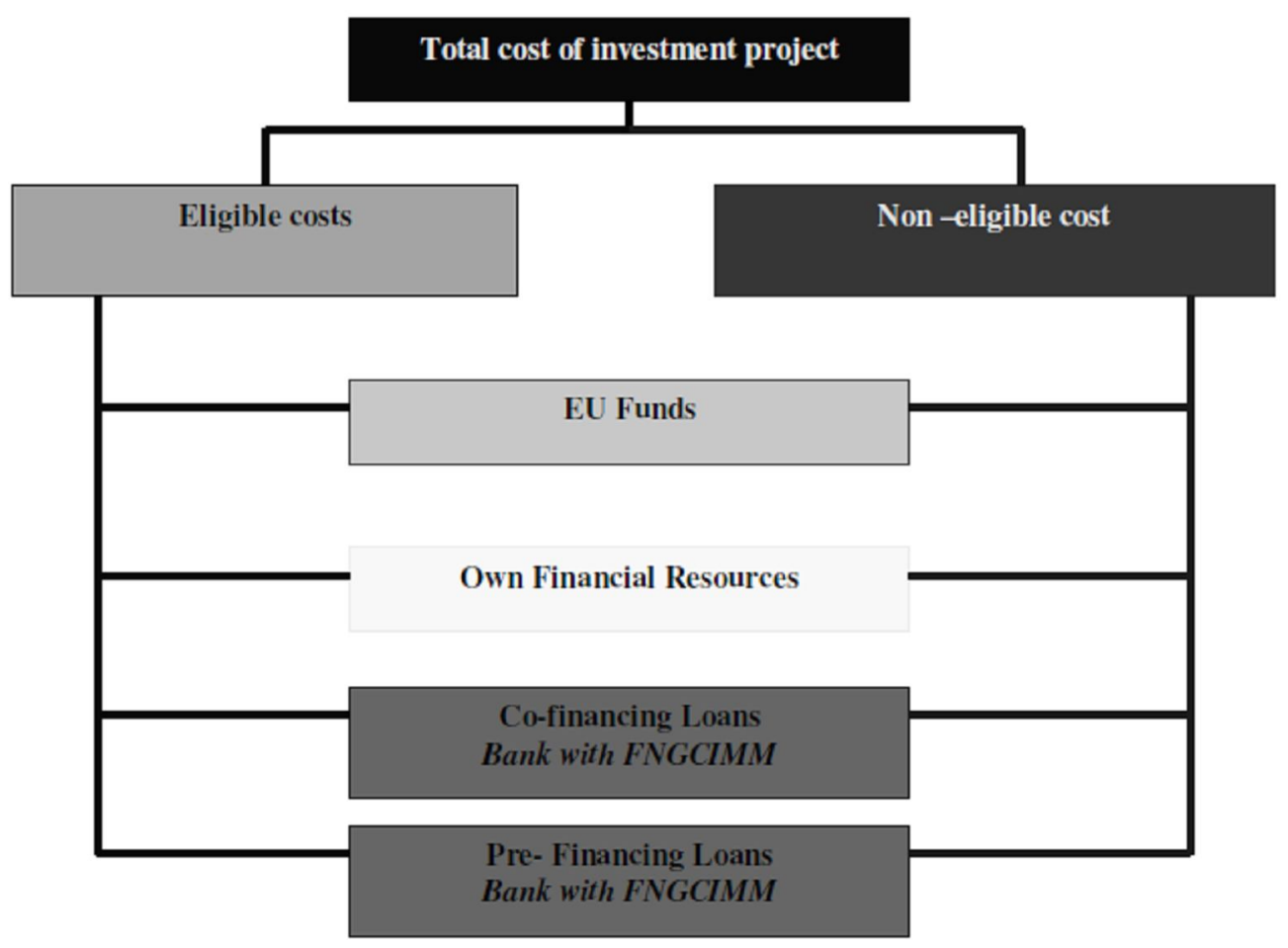

Figure 3. Financing mechanism - European Funded projects

(Adapted from "Ghid de Informare Privind Fondurile Structurale”, edited by Fondul Național de Garantare a Creditelor pentru IMM-uri, 2008)

In conclusion as we can see the role of the banking system and of the FNGCIMM has become increasingly important in the last two years, in the field of European funding co-financing, especially since were launched the major SME development programs. Even if were not released comprehensive analysis, a FNGCIMM report suggests that the number of the SMEs benefiting the support of the banking sector and of FNGCIMM increased with more than 5000 companies in 2009 and the credit awarded reached the amount of 500 million Euros, supporting the creation and maintenance of 75.000 jobs(FNGCIMM, 2009). These figures represent an explosive increase of the banking systems position as presented at the beginning of this chapter by the White Charter of the Romanian SMEs Report from 2006.

\section{Conclusions}

The European Integration came with new challenges for the Romanian enterprises especially for the SMEs, the opportunities arising from operating on the European Single Market and the possibility for accession of European Structural Funds. In this context this article tackled with the issues regarding the access of the Romanian SME's to European funding. First the New Definition of SME's was presented as an important tool for implementing efficient measures in order to raise the accessibility of European and national financing programmes, which are designed to support the development and competitiveness of SMEs. Were presented the main types of SMEs: microenterprises, small and medium enterprises classified over three criteria: staff headcount, annual turnover and annual balance sheet.

Later within this paper were presented the most important two financing programs which offer support to the SME's and large enterprises in order to increase their competitiveness and to increase their productive capacity: The Regional Operational Programme - Major Field of Intervention 4.3 "Support the development of micro-enterprises" and Sectorial Operational 
Programme "Increase of Economic Competitiveness". Both programs were thoroughly analyzed and presented.

As observed also in the "Chapter 5 Involvement of the Banking Sector in the preparation and implementation stages of the private European funded investment projects" the main conclusions of this paper reflect that the increase in opportunities of using European Funds to finance private SME investments brought an increase of interest from the beneficiaries to use and request specialized banking services in order to facilitate the development, implementation and operation of these investment projects. Also, in this context, as analyzed by the author, FNGCIMM which in 2006 was a totally unimportant player in financing and guaranteeing SME investments became one of the most critical players on the market having reached, in 2009, 500 million Euros awarded credit for the development of SMEs in correlation with European Funds.

\section{References}

1. Consiliul National al Intreprinderilor Private Mici si Mijlocii din România (CNIPMMR), 2006, White Charter of Romanian SMEs, Bucureşti

2. European Commission, 1978. Council Directive 78/660/EEC of 25 July 1978, based on Article 54 (3) (g) of the Treaty on the annual accounts of certain types of companies, Official Journal L 222, p. 11-31, of 14 August 1978

3. European Commission, 1996. Commission Recommendation 96/280/EC of 3 April 1996 concerning the definition of small and medium-sized enterprises (Text with EEA relevance), published in Official Journal L 107, p. 4-9, of 30 April 1996

4. European Commission, 2003. Commission Recommendation 2003/361/EC of 6 May 2003 concerning the definition of micro, small and medium-sized enterprises (Text with EEA relevance), published in Official Journal L 124, p. 36-41, of 20 May 2003.

5. European Commission, 2005. The New SME Definition - User Guide and Model Declaration, Enterprise and Industry Publications, Brussels

6. European Commission, 2006. Council Regulation (EC) No 1083/2006 of 11 July 2006 laying down general provisions on the European Regional Development Fund, the European Social Fund and the Cohesion Fund and repealing Regulation (EC) No 1260/1999, published in the Official Journal L210, p. 25-78, Brussels

7. Fondul Național de Garantare a Creditelor pentru IMM-uri, 2008. Ghid de Informare Privind Fondurile Structurale, Bucureşti

8. Fondul Național de Garantare a Creditelor pentru IMM-uri, 2009. Comunicat de presă, Bucureşti, 25 septembrie 2009

9. Guvernul României - Ministerul Întreprinderilor Mici şi Mijlocii, 2009. Ghidul Solicitantului POS CCE Axa 1 Domeniul 1.1 - Sprijin Financiar în valoare de până la 1.075.000 lei acordat pentru investiții în IMM, Bucureşti

10. Guvernul României - Ministerului Dezvoltării, Lucrărilor Publice şi Locuințelor, 2009. “Ghidul Solicitantului - Axa prioritară 4 ,Sprijinirea dezvoltării mediului de afaceri regional şi local” Domeniul de intervenție 4.3. „Sprijinirea dezvoltării microîntreprinderilor”, Bucureşti, versiune 30 Octombrie 2009

11. Romanian Government - Ministry of Economy and Finance, 2007. Framework Document Sectorial Operational Programme "Increase of Economic Competitiveness", Bucureşti

12. Romanian Government - Ministry of Development Public Works and Housing, 2007. Regional Operational Programme, Bucureşti 